\title{
Identifying Hidden Factors Affecting Household Solid Waste Generation for an Effective Waste Management System
}

\author{
Tharindi R. Jayasekara* and Hemantha P. Dinugala** \\ University of Sri Jayewardenepura, Sri Lanka
}

\begin{abstract}
Current urbanization, rapid economic growth and changes in the consumption pattern are burning issues faced by the developing countries on solid waste management. Proper solid waste management should be implemented with the urbanization in order to manage the households' waste generation. There should be proper solid waste management strategies and techniques within the micro level. Identifying households' hidden factors affecting towards waste generation in households led the foundation to develop an accurate waste management system. The study was administrated in the Colombo district using 335 households taken from Maharagama Urban Council and KotikawattaMulleriyawa Pradeshiya Sabha. Solid waste generation in the household based on the low, middle and high income level was $0.12 \mathrm{Kg} /$ person/day, $0.17 \mathrm{Kg} / \mathrm{person} /$ day and $0.25 \mathrm{Kg} /$ person/day. The study found that hidden factors for waste generation in households were family consumption pattern, family background, nature of the waste collection and ways of treating waste. Recognizing the opportunities and challenges within the area provides a clear path for waste management.
\end{abstract}

Keywords: Hidden Factors, Per Capita, Households, Solid Waste, Waste Management

\section{Introduction}

The world is moving towards the urban future. People are having a more comfortable life; they explore new things and consume more. Rapid urbanization, industrialization, rising income of the people and a more sophisticated form of consuming are leading to an increasing amount of waste in the world. Therefore, solid waste is a burning issue in the world. All the materials used in the market will become a waste one way or another. Waste is generally considered useless and unwanted. Waste materials that are discarded from human activities are useless. These wastes are normally in the form of the solid where solid waste refers to the range of garbage arising from animal and human activities that are discarded as unwanted and useless (Leblanc, 2018). These solid wastes include household refuse, agricultural remnants, food left over, plastic bags, tins, cans, ash and packaging covers. These are considered as waste once they are discarded because they are no longer needed in their present form. Countries without the legal definition of Municipal Solid Waste (MSW) in relevant laws do not use the terms "municipal solid waste" in their native languages, and the waste categories can often be translated to English as "Ordinary Solid Waste", "Urban Solid Waste" or similar terms (Kawai and Tasaki, 2015). MSW mainly generates from residential activities. According to studies, MSW generated from developing countries indicates that 55-80\% of waste from households and commercial or market areas with varying quantities from the street, industries generate 10-30\% of waste (Miezah et al., 2015). MSW is one of a resource that creates value after discard, so it needs separation of waste before it can be subject to a meaningful process (Miezah et al., 2015). Source separation is one of the fundamental solution for this and also should have a better Solid Waste Management (SWM) model for the process. Although, environmentally solid waste management is one of an important challenge the world is currently facing where, this issue is bigger in developing countries (Guerrero et al., 2013). In developed countries their existing data from long term characterization studies and transparency in monitoring solid waste both at the local and national level (Hristovski et al., 2007). However, such data are virtually inexistence in developing countries due to institutional weakness (Aleluia and Ferrão, 2016; Marshall and Farahbakhsh, 2013). When considering the characteristics among urban areas in developing countries, they are quite common but waste management tactics 
should be context specific, locally sensible and owned by the community of concern (Aleluia and Ferrão, 2016; Marshall and Farahbakhsh, 2013).

\section{The Current Situation}

There are 20.97 million people in Sri Lanka and among them, 5,851,130 people live in the Western province. According to Western Province Council's Waste Management Authority, Sri Lanka generates 7000 metric ton of waste per day. Approximately $60 \%$ of total waste generation in Sri Lanka belongs to the Colombo District. Per capita solid waste generation is nearly $0.4 \mathrm{~kg}$ per day in Sri Lanka (EFL, 2017). In Colombo district, three out of four people $(77.6 \%)$ already live in urban areas. With urbanization and higher consumption, solid waste management is one of the emerging problems in the western province. It is important to identify current states of the issue and how immersive it will be before going for the recovery process. Therefore, this study focuses on estimating per capita solid waste generation within the micro level. Secondly, to develop strategies for better waste management it is important to identify factors affecting to generate waste within the source. This study attempts to identify hidden factors which are influencing households to generate waste.

\section{Literature Review}

Households' solid waste generation is an inevitable consequence due to production and consumption activities. As the standard of living and disposable income increase, consumption of goods and services is also increasing within the household. MSW generation and MSW generation per capita refer to indicators of environmental pressures humankind exert on the environment (Kawai and Tasaki, 2015). Per capita, solid waste generation is a useful measure to evaluate the intensity of waste generation and valuable indicator to compare waste management intensities among other cities in Sri Lanka or the world. Waste generation rate measured by the quantity of waste produced from a person per day. Therefore, estimating and prediction of MSW generation plays an important role in MSW management. Developing countries are not giving serious attention regarding future challenges of MSW generation. This is the leading reason for lack of sufficient awareness of MSW generators and their attitudes towards waste management (Das and Bhattacharyya, 2014). MSW generation rates are influenced by economic development, the degree of industrialization, public habits and local climates. Waste generation rate is influenced by the income level of the country. Higher the economic development and rate of urbanization, the greater the amounts of solid waste produced. Approximately 70 million Ton of waste is generated in South Asia per year with per capita values ranging from 0.12 to $5.1 \mathrm{Kg}$ per person per day (Hoornweg and Bhada-Tata, 2012). However, solid waste generation rate is varied based on population density in an area of concern (Thivyatharsan et al., 2016). The relationship between quantity and composition of the household solid waste varies with several socio-economic variables. Waste is a function of consumer's consumption so; the relationship between waste and consumption activities can be expressed using a model which predicts waste characteristics (Richardson and Havlicek, 1974).

In the Sri Lankan context, waste generation is $0.42 \mathrm{Kg}$ of per capita per day and the average household generation is $1.85 \mathrm{Kg}$ per household per day. Hence, family income is the most suitable parameter to indicate the living standard of the household, also illustrate a clear picture of household solid waste generation (Bandara et al., 2007). Household income, size and populations factors are important factors affecting the quantity and composition of solid waste. Other than that, there are multiple motives which are affecting the household to generate waste in their dwellings. Cultural, demographic factors, social pressure are some factors affecting waste generation. Main functional elements of the MSW management are the waste generation, waste handling and sorting, storage and processing at source, collection, sorting processing and transformation, transfer and transport and finally disposal (U.S. Environmental Protection Agency, 1976). In here most impactful element is the waste generation which will lead all the other functional elements in the process. Identifying factors affecting waste generation in the household provide adequate information to detect opportunities and challenges when forming waste management systems based on six aspects (Abdoli et al., 2016). Integrated Solid Waste 
Management System (ISWM) framework distinguishes six aspects to be considered which are environmental, political/ legal, institutional, socio-culture, financial/economics and technical (Klundert et al., 2001).

\section{Methodology}

\section{Study Site}

The MSW stream should be identified and distinguish from other waste streams so that data on MSW generation can be appropriately captured (Kawai \& Tasaki, 2016). This study focused on household solid waste generation in the Colombo district as given in Figure 1 taken from Central Environment Authority (CEA). A statistically designed procedure was used to determine the accurate number of households' in the sample. Two clusters are selected from the Colombo district representing $75 \%$ of the urban population from Maharagama Urban Council (UC) and $25 \%$ of the rural population from Kotikawatte-Mulleriyawa Pradeshiya Sabha (PS). At the second stage of sampling, four Grama Niladari (GN) Divisions from Maharagama UC and two GN divisions from Kotikawatte-Mulleriyawa PS were randomly drawn for the study. Finally the systematic sampling was applied to lanes with in selected areas in order to access households easily.

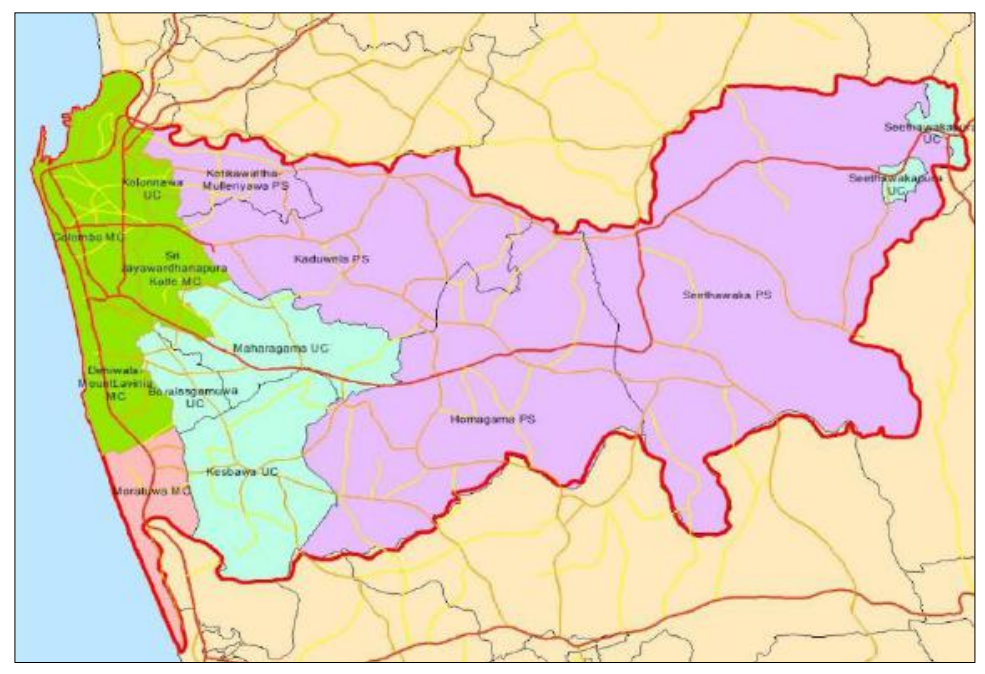

Figure 1: Location of the study area at Colombo District in the Western province.

\section{Data Collection and Data Analysis}

A fully structured questionnaire which had three sections where first section capture the socio-economic and demographic factors of the household, second section capture the information on waste generation and its' composition and last section capture the household waste management. This questionnaire was given to 403 households, but because of the absence of some households during sampling days, forgetting to respond back for the given questionnaire and due to miss-filling and error-filling the final number of sample obtained was 335 households. Each household was given one week to measure the weight of the waste which was categories as food residues, polythene/plastic, paper and mixed waste. Respondents' income was categories as low, middle and high income household using pre-identified categories. Data were collected to identify hidden factors of the waste generation based on six dimensions such as the motivational, cultural, behavioural, collection, age and attitude using a five-point Likert scale for 20 variables. Factor analysis was used to recognize hidden factors influencing towards waste generation in the household. Households' opinion regarding waste collection was analysed using content analysis. Meanwhile, interviews were conducted with representative from waste management division in CEA and representatives from selected UC and PS to gather data for the study by using 
schedule and secondary data were gathered from their past records. Apart from that direct observations were done when in the field visit to check how household manage their waste and how they dispose waste. Finally, cross check the most respondent's answers with their actual background to confirm the reliability of their responds. Data were subject to a range of statistical analysis and it was analysed using SPSS statistical package (Version 22).

\section{Results and Discussion}

Respondent's demographic profile led foundation to strength the survey results. When considering respondent's education level which represents in figure 2 shows respondents are well educated in this survey. Majority of the respondents $(41 \%)$ were graduated or go beyond that while only $1 \%$ of the respondents were never been to the school. In the sample $95 \%$ of the respondents were at least passed GCE O/L or above. Average age of respondent is 41 years old and age was slightly symmetrical (skewness is 0.471). Therefore, respondents are matured enough to validate the survey results.

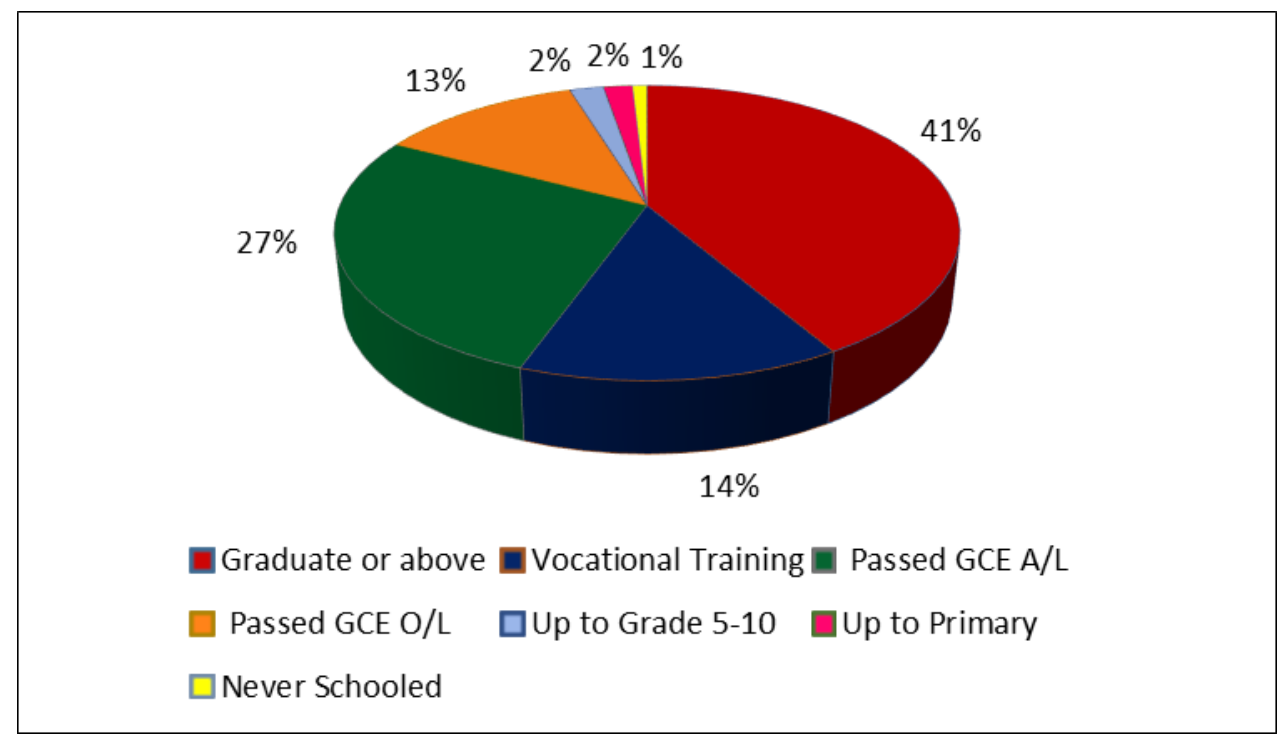

Figure 2: Respondents Education Level

Analysis of two sample t-test proves that there is no significant difference between urban and rural waste generation $(p=0.835)$ in the Colombo district apart from its definition given by the Department of Census and Statistics. Therefore, per capita waste generation rate can be taken for the whole sample. Hence, per capita waste generation rate by three different household categories per day was $0.12 \mathrm{Kg}, 0.17 \mathrm{Kg}$ and $0.25 \mathrm{Kg}$ with respect to the standard deviation of $0.0378,0.052$ and 0.083 for low, middle and high income household respectively. The results showed that the income of the household has a significant effect on waste generation. This value can further be classified as presented in Table 1. As seen in Table 1 food, polythene/ plastic and paper waste generation is higher in high-income households' than the other two income groups but, waste which is not separated is significantly low compared to the other two income groups. High-Income households' waste composition is highly consisting of food residues while the other two categories waste highly consisting of not separated waste. Moving on, paper waste has a considerable proportion of household waste composition. Average waste generation in household per day is $1.63 \mathrm{Kg}, 1.22 \mathrm{Kg}$ and $0.82 \mathrm{Kg}$ for high, middle and low income households. It is clearly seen that the income level of the household has a significant impact on waste segregation.

Table 1: Mean waste generation in household per day within three income groups

\begin{tabular}{|c|c|c|c|}
\hline Waste Type & High Income Group & Middle Income Group & Low Income Group \\
\hline
\end{tabular}




\begin{tabular}{lccc}
\hline Food Residues & 1.15 & 0.8 & 0.5 \\
\hline Polythene/plastic & 0.12 & 0.11 & 0.07 \\
\hline Paper & 0.16 & 0.14 & 0.08 \\
\hline Not Separated & 0.2 & 0.17 & 0.17 \\
\hline Total & 1.63 & 1.22 & 0.82 \\
\hline
\end{tabular}

Waste collection by the household is an important section to consider when making decisions regarding waste generation and waste management. At the household level waste collection begins with the person who is responsible for collecting waste within the household. Figure 3 represents the responsible party for collecting waste in their household. Majority of the households' waste was collected by the wife (51\%) which is highly influenced as an effect of culture. Hence, $2 \%$ of other category represents in-law's contribution towards waste collection in households'. Children's have a minor contribution towards waste collection and their involvements in these activities are highly insignificant. According to interviews with CEA personals state they have been conducted awareness programs regarding waste management for school children. Furthermore, under the subject of environmental studies students are learning 3R (Reduce, Reuse and Recycle) concept. Therefore, children's have more knowledge than parents regarding waste collections and controlling waste, but most of them do not practically involve in waste collection in households.

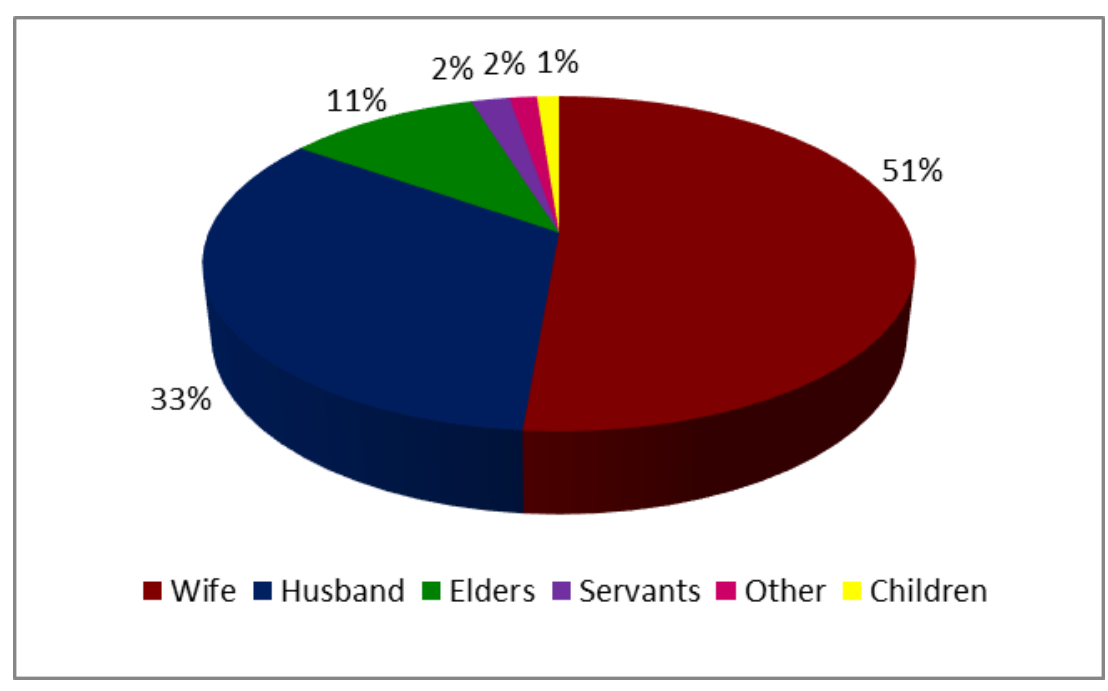

Figure 3: Person who is responsible for waste collection in household

However, considering the waste collection by UC and PS, $67.2 \%$ of the households said waste is collected by the council on time but $32.8 \%$ said the waste collection is unstable. As the opinion given by the respondents waste collection is not properly and frequently happens because of UC or PS (mostly UC) does not have enough vehicles, vehicle breakdowns, low staff and equipments, some residents have to pay money to collect waste (except food waste other minor waste like paper/ polythene/ glass and metal), worker strikes, waste pickers tend to avoid collecting waste if they do not get paid by the residents, waste pickers are not coming regularly and there is no direct supervision by the UC or PS for this issue. According to Maharagama UC's health officer there is a high rate of vehicle breakdown happens because of poor knowledge on operating these vehicles. Due to this improper ways of collecting waste residents tend to dispose of garbage in main road bins or an illegal manner in order to get rid of their waste. Some may throw the garbage bags in the pedestrian line, drainage or cross streets.

To have a proper waste collection plan UC and PS should have to recognise what causes the household to generate waste and its' rate as mention aforesaid. Correlation matrix of 20 variables which was identified under six dimensions has proven that there is no multicollinearity effect within any variable. A good reliability sample 
carried by Cronbach Alpha value (0.898) and validate by KMO value (0.888). Used principal component method to data reduction which was proven by $5 \%$ level of significance from Bartlett's test of Sphericity. Four factors had been extracted where this can be identified using the scree plot in appendix 1. Extraction of the four factors has been accounted for $55.199 \%$ of the total variance after using the Varimax factor rotation method. Therefore, family consumption pattern, family background, nature of the waste collection and ways of treating waste were identified as hidden factors which influenced the household solid waste generation.

Table 2: Waste management opportunities and challenges within the area

\begin{tabular}{|c|c|c|}
\hline Aspects & Opportunities & Challenges \\
\hline \multirow{3}{*}{$\begin{array}{l}\text { Technical and } \\
\text { Performance }\end{array}$} & $\begin{array}{l}\text { Develop innovative substitutes for } \\
\text { harmful waste }\end{array}$ & $\begin{array}{l}\text { Considering infrastructure within the } \\
\text { country when implementing the current } \\
\text { system }\end{array}$ \\
\hline & $\begin{array}{l}\text { Invest in new composting plants and } \\
\text { recycling business }\end{array}$ & $\begin{array}{l}\text { Collecting separated waste on different } \\
\text { vehicles }\end{array}$ \\
\hline & $\begin{array}{l}\text { Use of smart waste management } \\
\text { system in households }\end{array}$ & Managing current waste in the dump sites \\
\hline \multirow{4}{*}{ Political and Legal } & Regulate laws for illegal dumping & Changing attitudes of the households \\
\hline & $\begin{array}{l}\text { Improve concepts like pay as you } \\
\text { throw }\end{array}$ & Improve facility performances \\
\hline & $\begin{array}{l}\text { Can get the residents attraction by } \\
\text { implementing an effective waste } \\
\text { management system }\end{array}$ & $\begin{array}{l}\text { Complete transparency standards on new } \\
\text { rules and regulations }\end{array}$ \\
\hline & $\begin{array}{l}\text { Effective utilization of waste as a } \\
\text { resource }\end{array}$ & $\begin{array}{l}\text { Changing the current administrative system } \\
\text { in waste management }\end{array}$ \\
\hline \multirow[b]{3}{*}{ Institutional } & Generating new business ideas & Sales of recycled products \\
\hline & Contribution to the national GDP & High initial investment cost \\
\hline & $\begin{array}{l}\text { Reduce the amount of non- } \\
\text { biodegradable waste keep in } \\
\text { households }\end{array}$ & $\begin{array}{l}\text { Getting } 100 \% \text { separated waste from } \\
\text { households }\end{array}$ \\
\hline \multirow{3}{*}{ Social Cultural } & $\begin{array}{l}\text { Reduce diseases like dengue and } \\
\text { other skin rashes }\end{array}$ & $\begin{array}{l}\text { Getting informal waste pickers under } \\
\text { council employees }\end{array}$ \\
\hline & $\begin{array}{l}\text { Increase the standard of living in } \\
\text { households }\end{array}$ & $\begin{array}{l}\text { Change of traditional waste disposable } \\
\text { habits }\end{array}$ \\
\hline & $\begin{array}{l}\text { Generate additional household } \\
\text { income }\end{array}$ & $\begin{array}{l}\text { Getting the residents contribution to } \\
\text { community waste management programs }\end{array}$ \\
\hline \multirow{3}{*}{ Environmental } & $\begin{array}{l}\text { Clean environment in the } \\
\text { neighbourhood }\end{array}$ & Minimizing GHG and leachate \\
\hline & $\begin{array}{l}\text { Can protect animals from eating } \\
\text { plastic and other harmful waste }\end{array}$ & Public protest on new systems \\
\hline & Can get the tourist attraction & $\begin{array}{l}\text { Protecting the ecosystem and } \\
\text { environmental habitat }\end{array}$ \\
\hline \multirow{2}{*}{$\begin{array}{l}\text { Finance and } \\
\text { Economic }\end{array}$} & Low-cost collecting methods & Sustainable use of resources \\
\hline & Can gain foreign income & High capital cost \\
\hline
\end{tabular}

Before developing or implementing waste management systems authorities have to consider challenges and opportunities with in areas based on six aspects of ISWM as seen in Table 2 which is generated using data collected throughout the survey. This facilitates authorities to narrow down the issues when testing accurate waste management solutions. This cans also use as a breakpoint to recognize feasibility of solution to be taken and openings to a sustainable future. 


\section{Conclusion}

As the economy grows, urbanization has risen without any limitation. Consequently mountains of solid waste generated in Sri Lanka without any treatments as a side effect. Approximately solid waste consists of 50\%-60\% readily biodegradable waste and rest are inorganic components. The moisture content in the MSW is also very high in the range of 70-80\% on a wet weight basis (Bandara, 2008). Therefore, treatments with respect to waste have to be done quickly to stop future consequences. As a result of improper waste disposal, most of the streets especially cross streets are mucky and have a bad odour which affects resident's daily life. Sometimes garbage bags block the drainages and that will leads to spreading mosquitos and floods during the raining season within the area. When the waste is not collected by the council on time some residents dispose of their garbage near the streets rather than keeping it in their house for while or find a remedy to dispose of it in any form. Therefore, stray dogs, cows and cats damage the garbage bags pollute the environment and when in rainy seasons this situation is even worse. There is a high chance of having mosquito bone diseases, virus flu and skin rashes due to unmanaged waste in households. Waste issues are solid proof of ineffective waste management within the area.

Residents and authorities in Colombo district should have a sense of foreseeing the future risk. In line with findings majority of the residents in Colombo district are educated and matured to understand the consequences of mounting garbage. Therefore, authorities should have to design awareness programs that catch the public eye. Thus, the rate of waste generation and factors affecting to generate waste in the household have to be considered when developing practicable waste management systems for the household which is marked as the highest waste generation source. Identified factors affecting to waste generation is useful to improve environmental friendly novel business ideas and UC/PS can educate households to manage waste by targeting these factors.

\section{Reference}

Abdoli, M.A.; Rezaei, M.; Hasanian, H., (201 6). Integrated solid waste management in megacities. Global J.Environ. Sci. Manage. 2 (3): 289-29 8

Aleluia, J. and Ferrão, P. (2016). Characterization of urban waste management practices in developing Asian countries: A new analytical framework based on waste characteristics and urban dimension. Waste Management, 58, pp.415-429.

Bandara, N. (2008). Municipal Solid Waste Management - The Sri Lankan Case. In: Conference on Developments in Forestry and Environment Management. Department of Forestry and Environmental Science, University of Sri Jayewardenepura.

Bandara, N., Hettiaratchi, J., Wirasinghe, S. and Pilapiiya, S. (2007). Relation of waste generation and composition to socio-economic factors: a case study. Environmental Monitoring and Assessment, 135(1-3), pp.31-39.

Das, S. and Bhattacharyya, B. (2014). Estimation of Municipal Solid Waste Generation and Future Trends in Greater Metropolitan Regions of Kolkata, India. Journal of Industrial Engineering and Management Innovation, $1(1)$, pp.31-38.

Environment Foundation (Guarantee) Limited. (2017). Status of Waste Management in Sri Lanka. [Online] Available at: https://efl.lk/status-waste-management -Sri-Lanka/ [Accessed 12 Nov. 2017].

Guerrero, L., Maas, G. and Hogland, W. (2013). Solid waste management challenges for cities in developing countries. Waste Management, 33(1), pp.220-232. 
Hoornweg D, Bhada-Tata P (2012) What a waste: a global review of solid waste management. Urban development series; knowledge papers no 15 World Bank, Washington, DC.

Kawai, K. and Tasaki, T. (2015). Revisiting estimates of municipal solid waste generation per capita and their reliability. Journal of Material Cycles and Waste Management, 18(1), pp.1-13.

Klundert, A., Anschutz, J. and Scheinberg, A. (2001). Integrated sustainable waste management -a set of five tools for decision-makers - experiences from the urban waste expertise programme. Gouda: WASTE

Leblanc, R. (2018). An Introduction to Solid Waste Management. [online] The Balance Small Business. Available at: https://www.thebalancesmb.com/an-introduction-to-solid-waste-management-2878102 [Accessed 15 Mar. 2019].

Marshall, R. and Farahbakhsh, K. (2013). Systems approaches to integrated solid waste management in developing countries. Waste Management, 33(4), pp.988-1003.

Miezah, K., Obiri-Danso, K., Kádár, Z., Fei-Baffoe, B. and Mensah, M. (2015). Municipal solid waste characterization and quantification as a measure towards effective waste management in Ghana. Waste Management, 46, pp.15-27

Richardson, R. and Havlicek, J. (1974). An Analysis of Seasonal Household Waste Generation. Southern Journal of Agricultural Economics, 6(02), pp.143-155.

Thivyatharsan, R., Muhilini, J. and Dasinaa, S. (2016). Estimation and characterization of municipal solid waste generation in Thirukkovil Pradeshiya Sabha, Ampara District. International Journal of Multidisciplinary Studies, 3(1), pp.25-33.

U.S. Environmental Protection Agency (1976). Decision-Makers guide in solid waste management. Washington D.C.: U.S. Government Printing Office.

\section{Appendix}

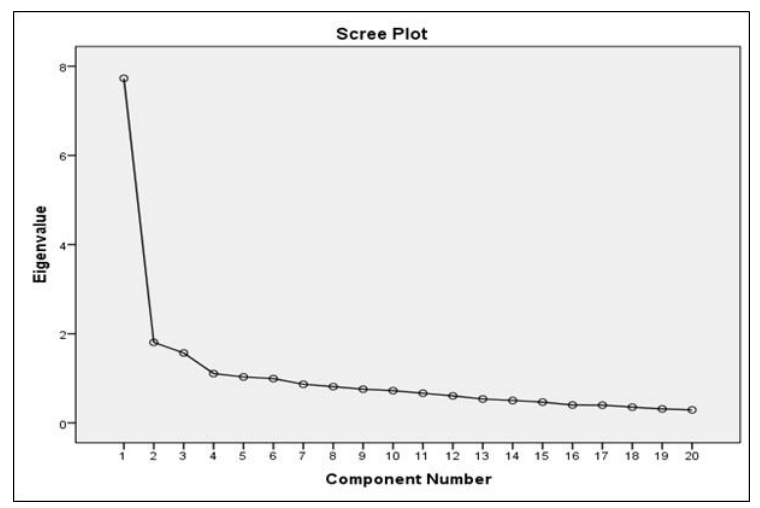

Appendix 1: Scree Plot of the solid waste generation factor analysis 